\title{
Un conejito en el abdomen
}

\section{A Bunny in the Abdomen}

\author{
María Agustina De Andreis ${ }^{1}$
}

${ }^{1}$ Servicio de Diagnóstico por imágenes, Hospital Interzonal General de Agudos San Martín, La Plata, Buenos Aires, Argentina

Rev Argent Radiol 2022;85(Suppl S1):S15-S16.

El tronco arterial celíaco es la primera rama originada en la cara anterior de la aorta abdominal, generalmente a nivel del borde superior de la primera vértebra lumbar. Luego de su emergencia aórtica, se divide normalmente en tres ramas: gástrica izquierda, hepática común y esplénica. Es posible encontrar distintas variantes de esta clásica división.

En la siguiente tomografía axial de abdomen con contraste endovenoso en fase arterial, se observa el nacimiento independiente de la arteria hepática y la arteria esplénica (-Figs. 1A y B). Dicha variante anatómica remeda la cabeza de un conejo y sus típicas orejas de bunny (-Fig. 2).
Address for correspondence María Agustina De Andreis, Calle $28 \mathrm{~N}^{\circ}$ 359 entre 39 y 40, Servicio de Diagnóstico por imágenes, Hospital Interzonal General de Agudos San Martín, La Plata, Buenos Aires, Argentina (e-mail: agus.deandreis@hotmail.com).

\section{Responsabilidades éticas}

Protección de personas y animales. La autora declara que para esta investigación no se han realizado experimentos en seres humanos ni en animales.

Confidencialidad de los datos. La autora declara que han seguido los protocolos de su centro de trabajo sobre la publicación de datos de pacientes.

Derecho a la privacidad y consentimiento informado. La autora declara que en este artículo no aparecen datos de pacientes.
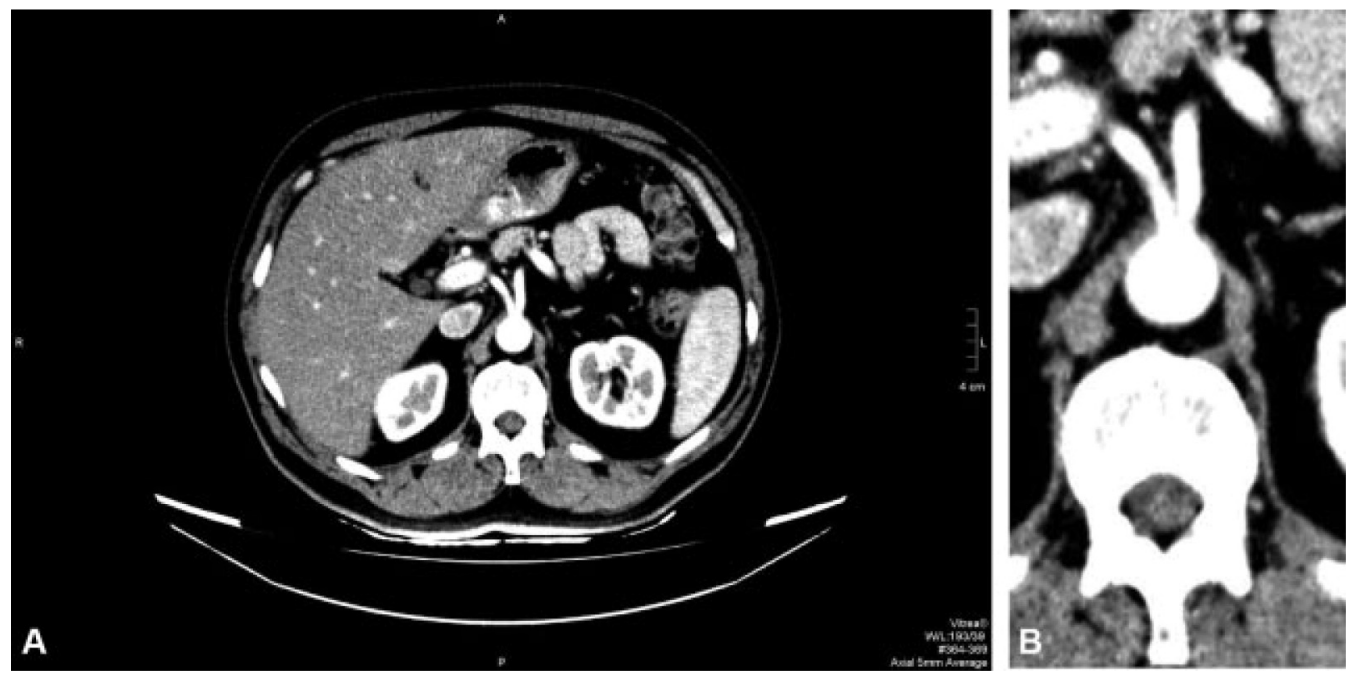

Fig. 1 (A) Corte axial de tomografía de abdomen con contraste endovenoso en fase arterial. Se evidencia una de las variantes anatómicas del tronco celíaco, visualizándose el nacimiento independiente de la arteria hepática y la arteria esplénica. (B) Ampliación del nacimiento independiente de las arterias.

received

May 7, 2020

accepted

July 23, 2020

published online

May 14, 2021
DOI https://doi.org/

10.1055/s-0040-1715804. ISSN 1852-9992.
(C) 2021. Asociación Civil Sociedad Argentina de Radiología and Federacion Argentina de Asociaciones de Radiología, Diagnóstico por Imágenes y Terapia Radiante. All rights reserved.

This is an open access article published by Thieme under the terms of the Creative Commons Attribution-NonDerivative-NonCommercial-License, permitting copying and reproduction so long as the original work is given appropriate credit. Contents may not be used for commercial purposes, or adapted, remixed, transformed or built upon. (https://creativecommons.org/ licenses/by-nc-nd/4.0/)

Thieme Revinter Publicações Ltda., Rua do Matoso 170, Rio de Janeiro, RJ, CEP 20270-135, Brazil 


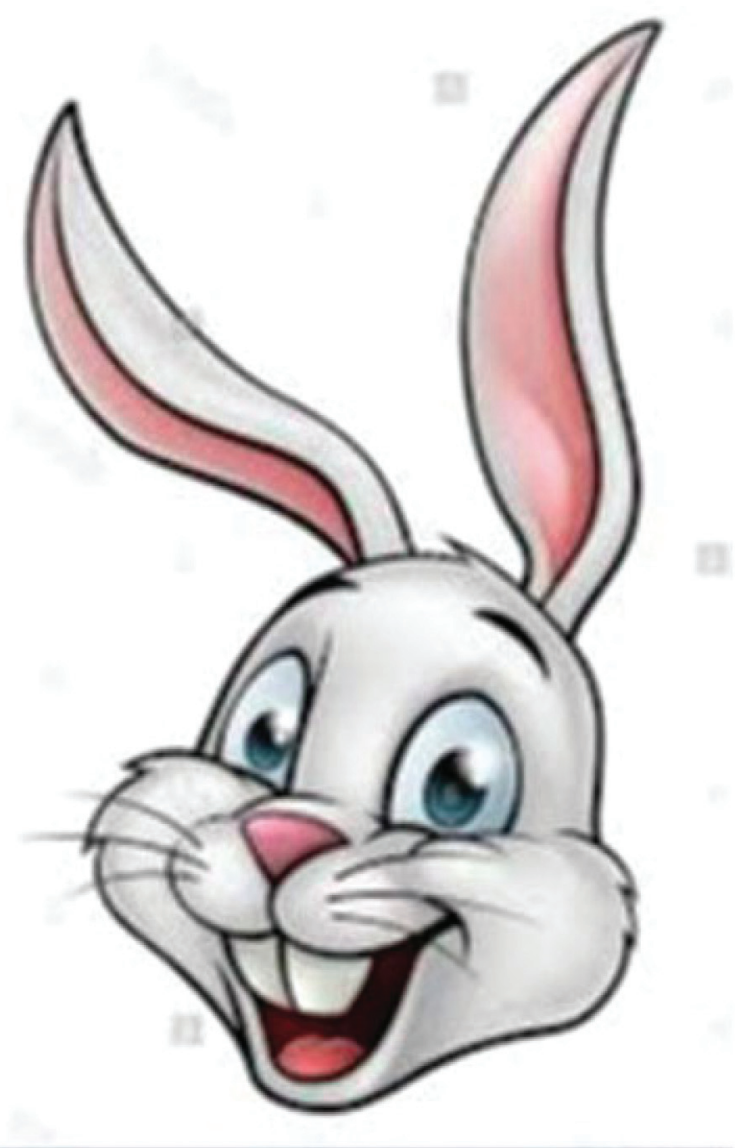

Conflicto de Intereses

Los autores declaran no tener ningún conflicto de intereses.

\section{Agradecimientos}

La autora agradece a la Dra. Jimena Mariano, médica de planta del Servicio de Diagnóstico por Imágenes del Hospital Interzonal General de Agudos San Martín de La Plata y a la Dra. María Paula Seguí, jefa de residentes del Servicio de Diagnóstico por Imágenes del Hospital Interzonal General de Agudos San Martín de La Plata.

Fig. 2 Caricatura de conejo. 